Peer Reviewed Paper openaccess

\title{
Applying spectral analysis for identification of alteration zones in north Saveh area, Iran
}

\author{
Kazem Rangzan, ${ }^{\mathrm{a}, *}$ Somayeh Beyranvand, ${ }^{\mathrm{b}}$ Hoshang Pourkaseb, ${ }^{\mathrm{b}}$ Hojjatollah Ranjbar ${ }^{\mathrm{c}}$ and Alireza Zarasvandi ${ }^{\mathrm{b}}$ \\ aDepartment of Remote Sensing and GIS, Faculty of Earth Sciences, Shahid Chamran University of Ahvaz, Ahvaz, Iran \\ bDepartment of Geology, Faculty of Earth Sciences, Shahid Chamran University of Ahvaz, Ahvaz, Iran \\ ${ }^{`}$ Department of Mining Engineering, Faculty of Engineering, Shahid Bahonar University of Kerman, Jomhori Blvd., Kerman 7616914111, Iran \\ Contacts \\ K. Rangzan: kazemrangzan@scu.ac.ir \\ H. Ranjbar: hojjatranjbar@gmail.com \\ S. Beyranvand: s.beyranvand@yahoo.com \\ A. Zarasvandi: zarvasvandi_a@scu.ac.ir \\ H. Pourkaseb: h.pourkaseb@scu.ac.ir
}

An extensive series of volcanic rocks are exposed in the north of Saveh city, Iran, which consist of phyllic, argillic and propylitic hydrothermal alteration types. For the purpose of the investigation, a FieldSpec $3^{\circledR}$ spectroradiometer was used to measure the spectral response of the mineral content of these rocks. The spectral analyses of reflectance curve by The Spectral Geologist (TSG) software could discriminate kaolinite and montmorillonite (argillic), illite, muscovite, phengite and paragonite (phyllic), hornblende and chlorite, siderite (propylitic), hematite and goethite from the gossans. It also detected gypsum of hydrothermal alteration zones. The Advanced Spaceborne Thermal Emission and Reflectance Radiometer (ASTER) image, which was used for mapping the hydrothermal alteration minerals, contains the Visible and Near Infrared (VNIR) wavelengths between $0.52 \mu \mathrm{m}$ and $0.86 \mu \mathrm{m}$, Short Wave Infrared (SWIR) wavelengths between $1.6 \mu \mathrm{m}$ and $2.43 \mu \mathrm{m}$ and Thermal Infrared (TIR) wavelengths between $8.125 \mu \mathrm{m}$ and $11.65 \mu \mathrm{m}$ with 15,30 and $90 \mathrm{~m}$ spatial resolutions, respectively. For calibration of the ASTER images, the extracted spectra of different rocks and minerals were used for atmospheric and radiometric corrections. Mixture tuned matched filtering (MTMF) and Spectral Angle Mapper (SAM) were applied on ASTER data to map the hydrothermal alteration of minerals. The use of the spectroradiometry techniques in conjunction with other data exhibits the ability of these new methods for non-destructive and rapid identification of mineral types for more detailed investigation. The results show that the area has undergone different levels of hydrothermal alteration, so much so that phyllic, argillic and propylitic types of hydrothermal alteration are present in the study area. This may point to high potential and promising zones for the exploration of porphyry mineralisation.

Keywords: spectroscopy, ASTER image, alteration zones, Saveh-Iran, Urumieh-Dokhtar Arc

\section{Introduction}

Identification of the behaviour of the material at various wavelengths using reflective sensing data can be conducive to recognising and distinguishing types of occurrences in remote sensing data. ${ }^{1}$ Minerals show
Correspondence

K. Rangzan (kazemrangzan@scu.ac.ir)

Received: 27 July 2020

Revised: 16 October 2020

Accepted: 16 October 2020

Publication: 24 November 2020

doi: 10.1255/jsi.2020.a15

ISSN: 2040-4565

Citation
K. Rangzan, S. Beyranvand, H. Pourkaseb, H. Ranjbar and A. Zarasvandi,
"Applying spectral analysis for identification of alteration zones in north
Saveh area, Iran", J. Spectral Imaging 9, a15 (2020).
https://doi.org/10.1255/jsi.2020.a15
(C) 2020 The Authors
This licence permits you to use, share, copy and redistribute the paper in
any medium or any format provided that a full citation to the original
paper in this journal is given, the use is not for commercial purposes and
the paper is not changed in any way.


absorption features in the visible near infrared (VNIR) and shortwave infrared (SWIR) regions, which help to distinguish hydrothermal alteration zones. ${ }^{2,3}$ Infrared spectroscopy is extensively used for the recognition of hydrothermal alteration minerals., ${ }^{4,5}$ Rangzan et al. ${ }^{6,7}$ studied the spectral properties of the igneous and metamorphic rocks of the Hamedan region in Iran using a FieldSpec $3^{\circledR}$ spectroradiometer. In their work, they studied the spectral behaviour of the alumino-silicate minerals as well as the spectral classification of the rocks containing these minerals. In another study, Pourkaseb et al. ${ }^{8}$ used a spectroradiometer and extracted the spectra of the rock units of Firoozabad salt diapir of the Zagros mountain of southeast Iran. Karami et al. ${ }^{9}$ created a GIS database and interactive maps with spectral data sharing to show the possibility of the contribution of referenced spectral data in producing geo-information. Many authors have applied remote sensing techniques for mineral exploration. ${ }^{10-16}$

Azizi et al. ${ }^{17}$ applied ASTER SWIR data to identify hydrothermal alteration minerals from the Zanjan area, Iran. Honarmand et al. ${ }^{18}$ applied ASTER/Enhanced Thematic Mapper (ETM) images for the alteration mapping of Kerman, Iran. Amer ${ }^{19}$ used ASTER images and utilised Spectral Information Divergence (SID) and Spectral Angle Mapper (SAM) classification methods to detect altered minerals related to gold mineralisation in Egypt. The significance of the Mixture Tuned Matched Filtering (MTMF) method in enhancing the detection of altered minerals has already been revealed in many studies. ${ }^{20,21}$ Our study area is located in a part of the UrumiehDokhtar magmatic arc. It seems that the study area has been tectonically active, as revealed by the numerous faults, folds and fractures (Figure 1). Rock outcrops in the study area are dacitic lava, dacitic tuff, andesite, basaltic andesite, trachyandesite, rhyodacite, granite, diorite, granodiorite, gabbro-diorite, tonalite and quartz diorite, which are exposed in north Saveh, Iran. ${ }^{22}$ Moreover, the interaction of hot aqueous fluids with the country rocks produce hydrothermal mineral deposits. ${ }^{23,24}$ Lowell and Guilbert ${ }^{25}$ concluded that potassic, phyllic, argillic and propylitic zones are associated with porphyry copper deposits. Since the same situation may prevail in vast portions of Iran, spectroradiometric techniques were used for rapid investigation in the study area. Spectroradiometer and The Spectral Geologist (TSG) are standard and effective tools for mineral exploration. Additionally, the created spectra are used for various corrections of satellite images and accuracy assessment of classifications. Also, remote sensing can be used to detect and map hydrothermally altered rocks.

\section{Geological setting}

The Saveh area is located in the central part of the Urumieh-Dokhtar magmatic arc between $49^{\circ} 59^{\prime} 59^{\prime \prime}$

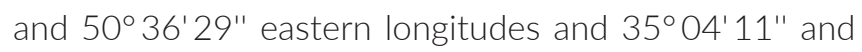
$35^{\circ} 15^{\prime} 54^{\prime \prime}$ northern latitudes. As mentioned above, it seems that the study area has been tectonically active, which is revealed by the numerous faults, folds and fractures (Figure 1). Rock outcrops in the study area are dacitic lava, dacitic tuff, andesite, basaltic andesite, trachyandesite, rhyodacite, granite, diorite, granodiorite, gabbrodiorite, tonalite and quartz diorite, which are exposed in north Saveh, Iran. The present-day geotectonic framework of Iran is strongly influenced by two major orogenic events, one in the Early Mid-Mesozoic time reflecting the closure of the Paleo-Tethys Ocean, and the second in the Early Cenozoic to Recent, reflecting the closure of the Neo-Tethys Ocean. ${ }^{26,27}$ The closure of Neo-Tethys and the consequent collisional tectonic regime resulted in the formation of the Zagros Structural Belt. ${ }^{28}$ It consists of three major tectonic units with an NW-SE trend in Iran, namely: (1) Zagros fold and thrust belt, (2) SanandajSirjan Metamorphic Zone and (3) Urumieh-Dokhtar magmatic arc (UDMA). ${ }^{29}$ The UDMA is considered as a tectonically active zone dominated by intermediate-silicic volcanoes as well as plutonic rocks composed mainly of quartz diorite and granodiorite. ${ }^{30-34}$ Magmatism in UDMA at first had tholeiitic nature, then changed to calc-alkaline and alkaline. ${ }^{35}$ A wide variety of porphyry $\mathrm{Cu} \pm$ Mo mineralisations have been reported and investigated along the UDMA. ${ }^{36}$ In the UDMA, there are at least two giant porphyry deposits, namely Sarcheshmeh [1200 million tons (Mt) at 0.7\% Cu and $0.03 \% \mathrm{Mo}]^{37}$ and Sungun (500 Mt at $0.7 \% \mathrm{Cu}$ and $0.01 \% \mathrm{Mo}$ ), ${ }^{38}$ one large porphyry deposit (Meiduk: $170 \mathrm{Mt}$ at $0.86 \% \mathrm{Cu}, 0.007 \%$ Mo, $82 \mathrm{ppb} \mathrm{Au}$ and $1.8 \mathrm{ppm} \mathrm{Ag),}{ }^{39}$ and at least three medium-sized porphyry deposits. Nevertheless, the fact is that compared with southern parts, the central parts of UDMA are not well understood. ${ }^{40,41}$ The Saveh area is located in the central part of the UDMA (Figure 1). As shown in Figure 1b, the oldest rocks cropping out in the study area include Eocene volcanogenic rock sequences, i.e. dacitic lava and tuff, with andesite and basaltic 


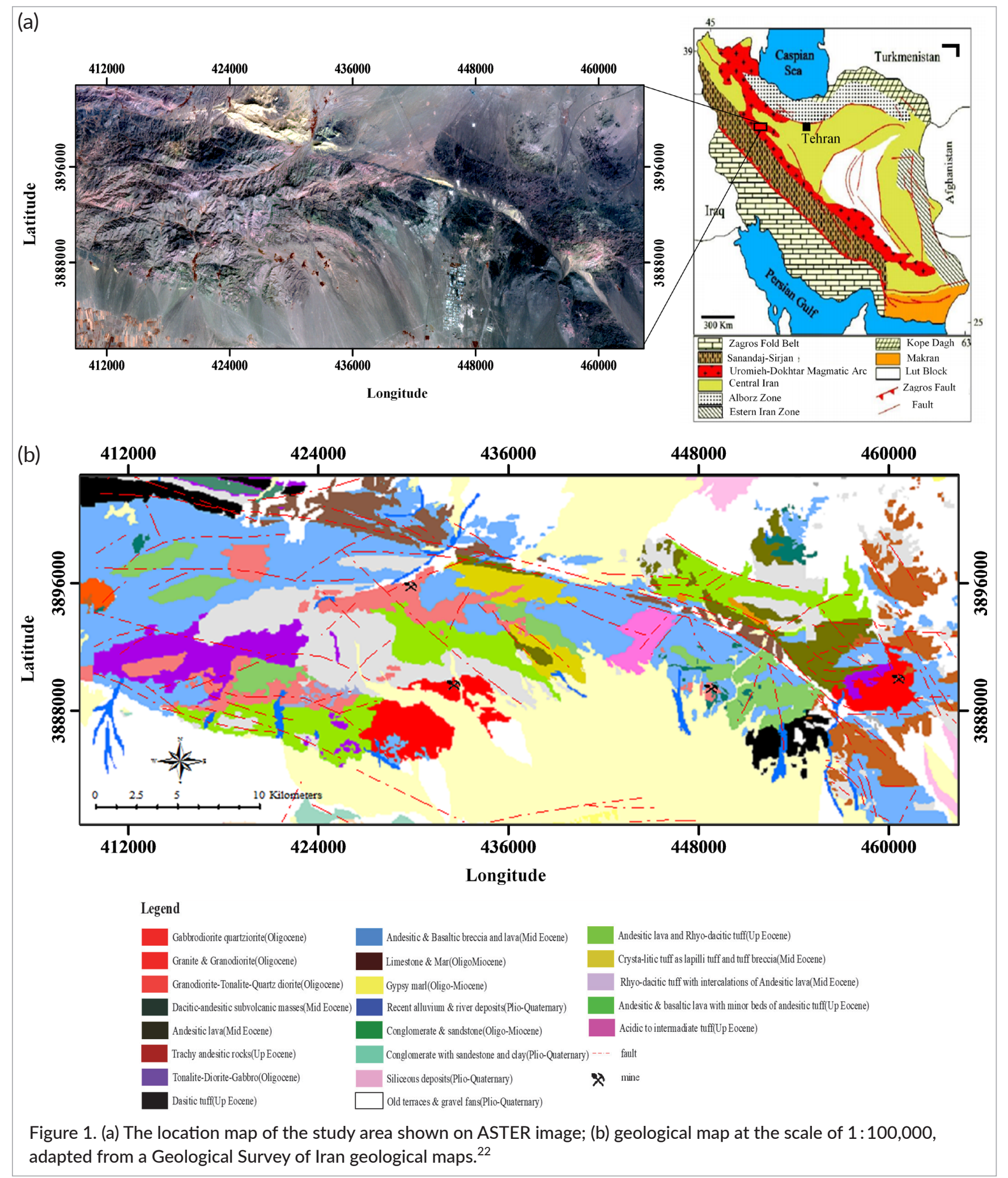

andesite, trachyandesite and rhyodacite. ${ }^{35}$ It is intruded by Oligo-Miocene intrusions which consist mainly of granite, diorite, granodiorite, gabbro-diorite, tonalite and quartz diorite. The displacement along WNW-ESE trend faults has affected granite, diorite, granodiorite, gabbrodiorite, tonalite and quartz diorite units. ${ }^{42}$ These rocks are overlaid by a sequence of Miocene gypsiferous marl having interlayers of sandstone and conglomerate that 
are covered by younger clastic rocks. ${ }^{22}$ Therefore, the present work aims are to utilise new technology based on the integration of spectroscopy and remote sensing analyses to have a wider view of the types of mineralisation zones that have been created by igneous activities. It is noteworthy that according to the knowledge of the authors, this integrated methodology has not been used to study alteration zones.

\section{Research methodology}

In this paper, the ASTER and ETM ${ }^{+}$images of 6 October 2003 and 25 July 2000, respectively, were used. The images were transferred from the USGS website (http:// earthexplorer.usgs.gov/). The ETM ${ }^{+}$image was used for geometric correction and the total RMS error of less than $2 \mathrm{~m}$ was calculated. The ETM ${ }^{+}$consists of eight spectral bands, that is six bands of data in the VNIR and SWIR spectral regions at a resolution of $30 \mathrm{~m}$, the panchromatic band and a thermal band with a spatial resolution of $60 \mathrm{~m}$ and $15 \mathrm{~m}$. Image-to-image geometric correction is performed by finding similar ground control points (GCPs) on two images. These points are selected in fixed areas with appropriate distribution and numbers. Moving points from their place in the image without geometric correction to their place in the image with geometric correction is the general pattern of this type of correction, which can be done in the ENVI software environment with high accuracy. As mentioned before, there are 14 spectral bands in ASTER data which consist of three bands of VNIR, six bands of SWIR and five bands of Thermal Infrared (TIR) with 15, 30 and $90 \mathrm{~m}$ spatial resolution, respectively. The coordinate of the images is between $49^{\circ} 59^{\prime} 59^{\prime \prime}$ and $50^{\circ} 36^{\prime} 29^{\prime \prime}$ eastern longitudes and $35^{\circ} 04^{\prime} 11^{\prime \prime}$ and $35^{\circ} 15^{\prime} 54^{\prime \prime}$ northern latitudes.

\section{ASTER image pre-processing}

To convert the digital number (DN) data of ASTER images into reflectance data, various processing methods such as cross talk, FLAASH atmospheric correction and layer stacking were carried out using ENVI software. ${ }^{43,44}$

\section{ASTER image processing}

To improve geological detail of the study area, various types of band ratios ${ }^{45-50}$ and False Colour Composite (FCC) combinations were used. ${ }^{51,52}$
Mixture Tuned Matched Filtering (MTMF) method Boardman et al..$^{20}$ used the MTMF technique to subpixel level for mapping target minerals from ASTER data. The MTMF algorithm uses the spectra extracted from the image or selected from a spectral library to compare them to the reference or field sample spectra in terms of mapping target minerals. The main steps in the MTMF algorithm are Minimum Noise Fraction (MNF) and Matched Filtering (MF). The MNF is necessary as input data for the MTMF algorithm. It means that MNF recognises the noise via the assessment from the covariance matrix and decreases the dimension of data via the range of standard principal components. ${ }^{53} \mathrm{MF}$ is used for abundance assessment and mixture tuning for identifying unacceptable or false-positive pixels. ${ }^{20} \mathrm{MF}$ and infeasibility are the results of this algorithm to evaluate the mapping process selected the pixels with low infeasibility and high MF in a two-dimensional space. ${ }^{20}$ The infeasibility image is used to reduce the number of false positives. False positives are sometimes found when using MF. Pixels having high infeasibility are expected to be MF false positives. Correctly mapped pixels will have an MF score more than the background distribution around zero and a low infeasibility value. The infeasibility amounts are in noise sigma units that vary in the DN scale with an MF score.

Spectral Angle Mapper (SAM) method

The SAM classification method is done by calculating the spectral similarity between the image spectrum and a reference spectrum and permits the rapid mapping of various minerals. ${ }^{54,55}$ Similar to the MTMF method, in the SAM algorithm, the reference spectra are taken directly from the image or extracted from laboratory or field measurements. Calculating the angle among the two spectra and treating them as vectors in $n$-dimensional space, measures the spectral resemblance is the basis of the SAM method. In this method, high similarity occurs when the angle between the two spectra is small and high angles depicts low similarity. ${ }^{56}$ This algorithm is an easy, fast and very powerful classification method for mapping the spectral likeness of image spectra to reference spectra. ${ }^{57}$

In this paper, the FCC, MTMF and SAM methods are employed to map the phyllic, argillic and propylitic mineral zones. The FCC method creates an image with an unusual colour to enhance a target. Furthermore, at this stage, a second field visit was conducted for sample collections 
from the areas enhanced by MTMF and SAM algorithms for further spectral analysis with a FieldSpec $3^{\circledR}$ and TSG.

\section{Spectral measurement FieldSpec $3^{\circledR}$ spectrometer}

The spectra of samples were measured using the FieldSpec $3^{\circledR}$ at the Shahid Chamran University of Ahvaz, Iran. The FieldSpec $3^{\circledR}$ spectrometer can measure the reflection of the target. This optical device is specifically applied for field and laboratory measurements which determine the spectral response of the targets in the VNIR and SWIR. The spectral range is $350-2500 \mathrm{~nm}$ with a collection time of $0.1 \mathrm{~s}$ for each spectrum. Rock outcrops in the study area which are andesite, basaltic, basaltic andesite, granite, granodiorite and tuff were measured using the FieldSpec $3^{\circledR}$.

\section{The Spectral Geologist ${ }^{\circledR}$ (TSG)}

TSG software (version 7.1.0.073 July 2017) ${ }^{58}$ developed by CSIRO, Australia, is the industry-standard tool for geological analysis of spectral reflectance data of minerals, rocks and soils with the help of the Spectral Assistant ${ }^{\top M}$ (TSA) subroutine. The benefits of using the TSA software are: it uses a fast subset selection routine, decides on the number of materials in the mixture, the concurrent assessment of the background and the mixture constituents, and the use of an estimated within-class covariance matrix to improve the classification accuracy. The current TSA SWIR library includes 60 classes that are kaoline (well-crystallised kaolinite, poorly crystallised kaolinite, dickite and nacrite); mica group (illite, muscovite, phengite and paragonite); other $\mathrm{AlOH}$ minerals (montmorillonite, prehnite, pyrophyllite, topaz); three varieties of chlorite (magnesium, iron and intermediate); amphiboles (tremolite, actinolite, hornblende and riebeckite); a variety of other $\mathrm{MgOH}$ and $\mathrm{FeOH}$ bearing minerals (biotite, phlogopite, nontronite, talc); sulphates (jarosite, gypsum and three varieties of alunite); carbonates (calcite, dolomite, ankerite, magnesite and siderite); epidote and opaline silica.

\section{Results and discussion ASTER processing}

In this paper, ASTER data spectroradiometry techniques and conventional methods such as MTMF and SAM are employed for detection and mapping of minerals in the phyllic, argillic and propylitic zones in the northern parts of Saveh, Iran.

FCC of bands 4,6 and 8 [band $4(1.6-1.7 \mu \mathrm{m})$, band $6(2.225-2.245 \mu \mathrm{m})$ and band $8(2.295-2.365 \mu \mathrm{m})]$ is a good band combination for the enhancement of phyllic, argillic and propylitic alteration zones due to the presence of absorption features at band 6 (Figure 2). Important minerals of phyllic and argillic alteration zones (AlOH minerals such as kaolinite, muscovite, montmorilIonite and illite) have a strong reflection in band 4, while, notable minerals of propylitic alteration zones $(\mathrm{MgOH}$ minerals such as chlorite and epidote) show high reflection in bands 5 and $6 .{ }^{59}$ By using the FCC468 image, alteration zones could be identified (Figure 3). In this FCC, the pink colour is related to argillic and phyllic zones, and green indicates propylitic zone. ${ }^{51,60}$

To get an overview of the area, a 468-colour combination was used, then a field visit was made in order to collect samples for spectroscopy. Based on a 468 FCC image of the area, field sampling sites were selected. The first sampling was performed on 11 February 2017 at two sites (Figure 4). The collected samples showed

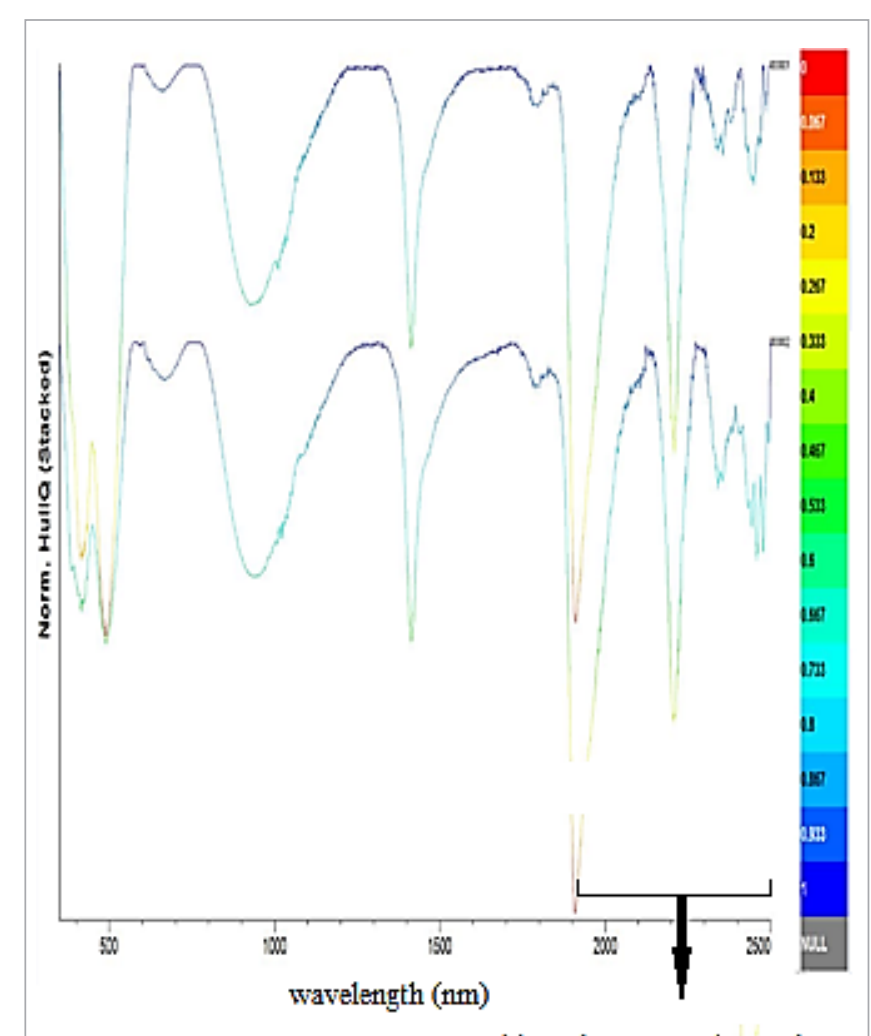

Alteration zones absorptions

Figure 2. Alteration zones absorptions. 


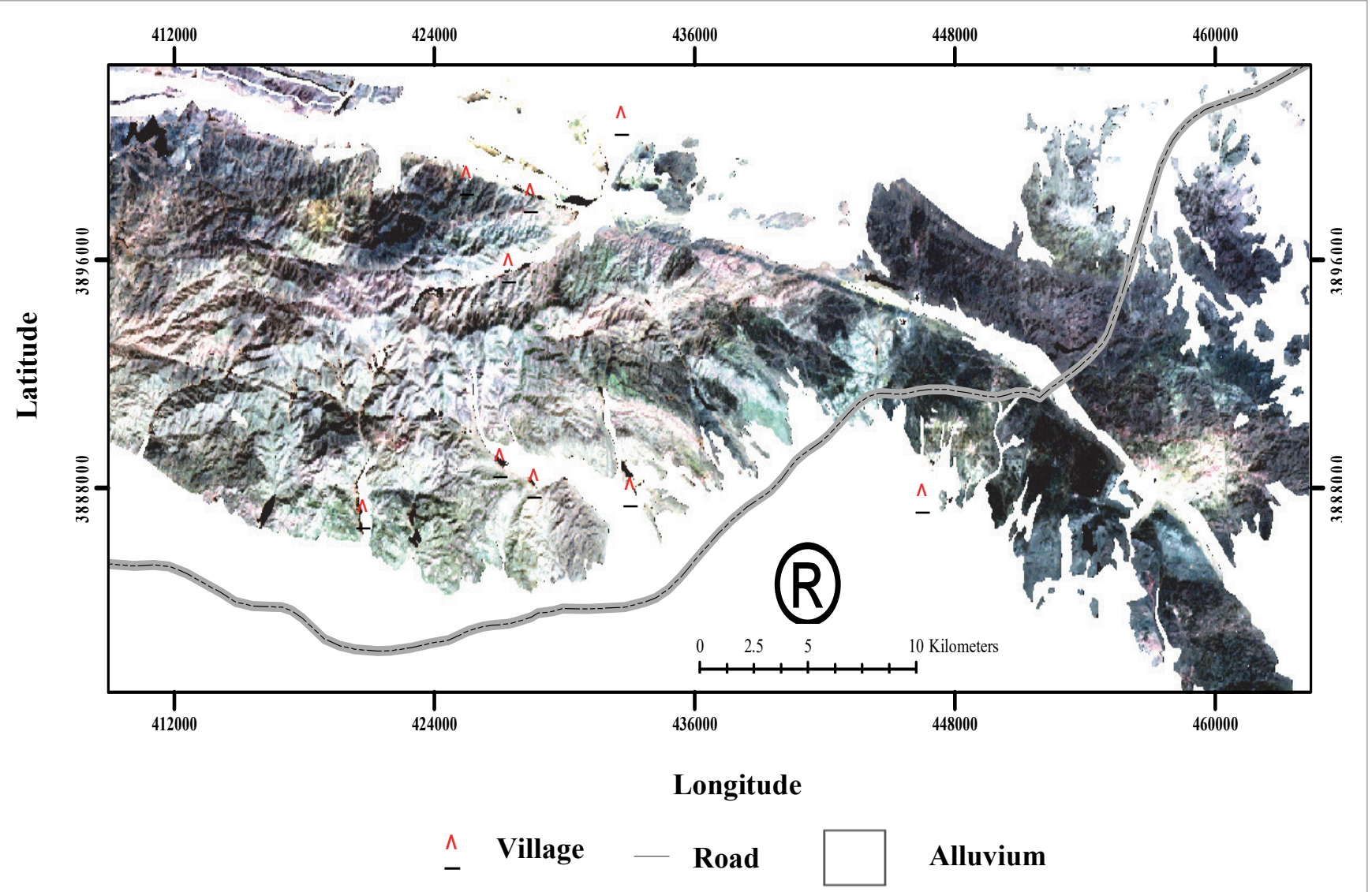

Figure 3. ASTER FCC468 image of the study area. In this image, phyllic and argillic alteration zones are pink and green colour shows a propylitic alteration zone.

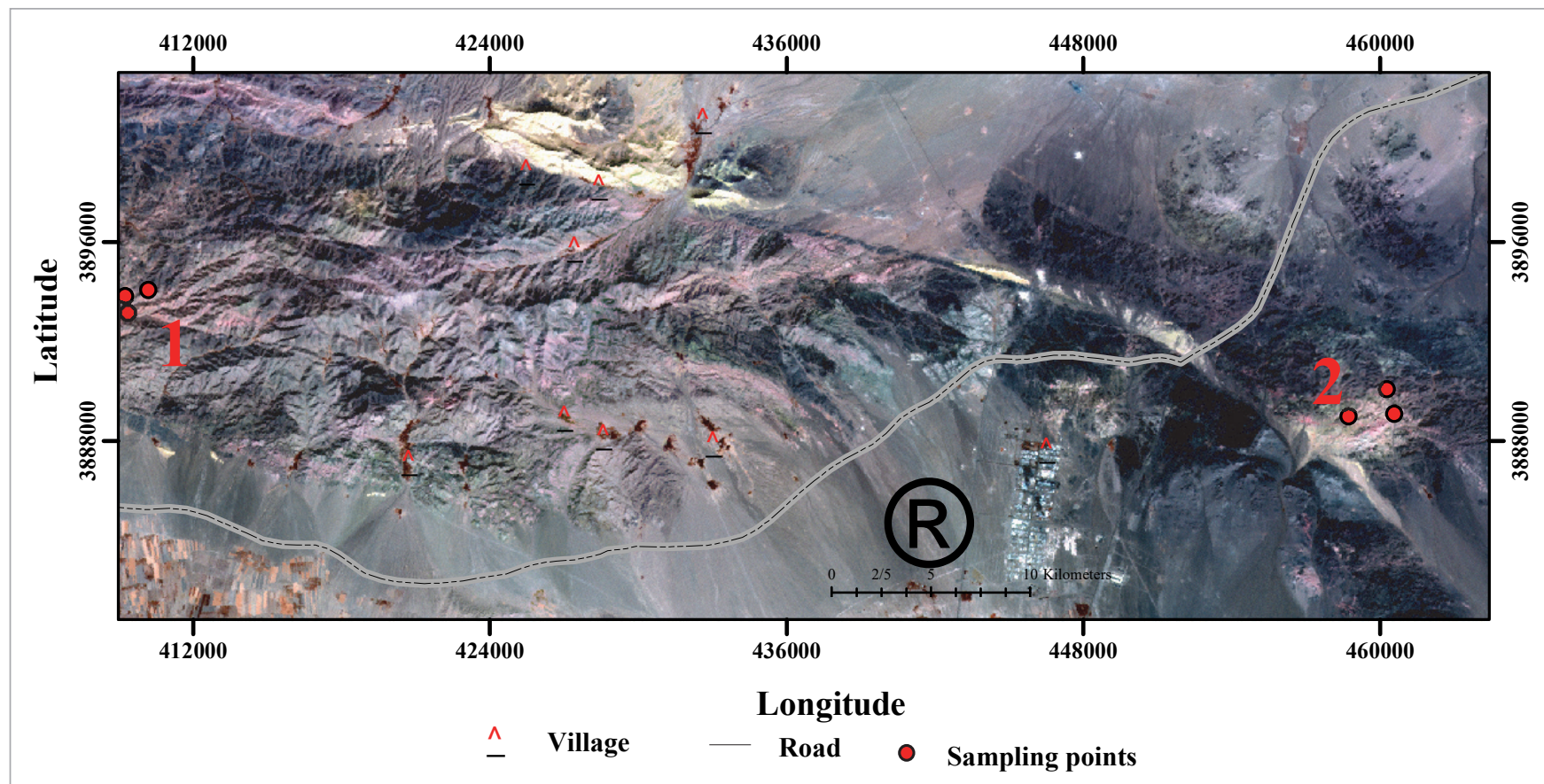

Figure 4. The first field sampling in the study area. 


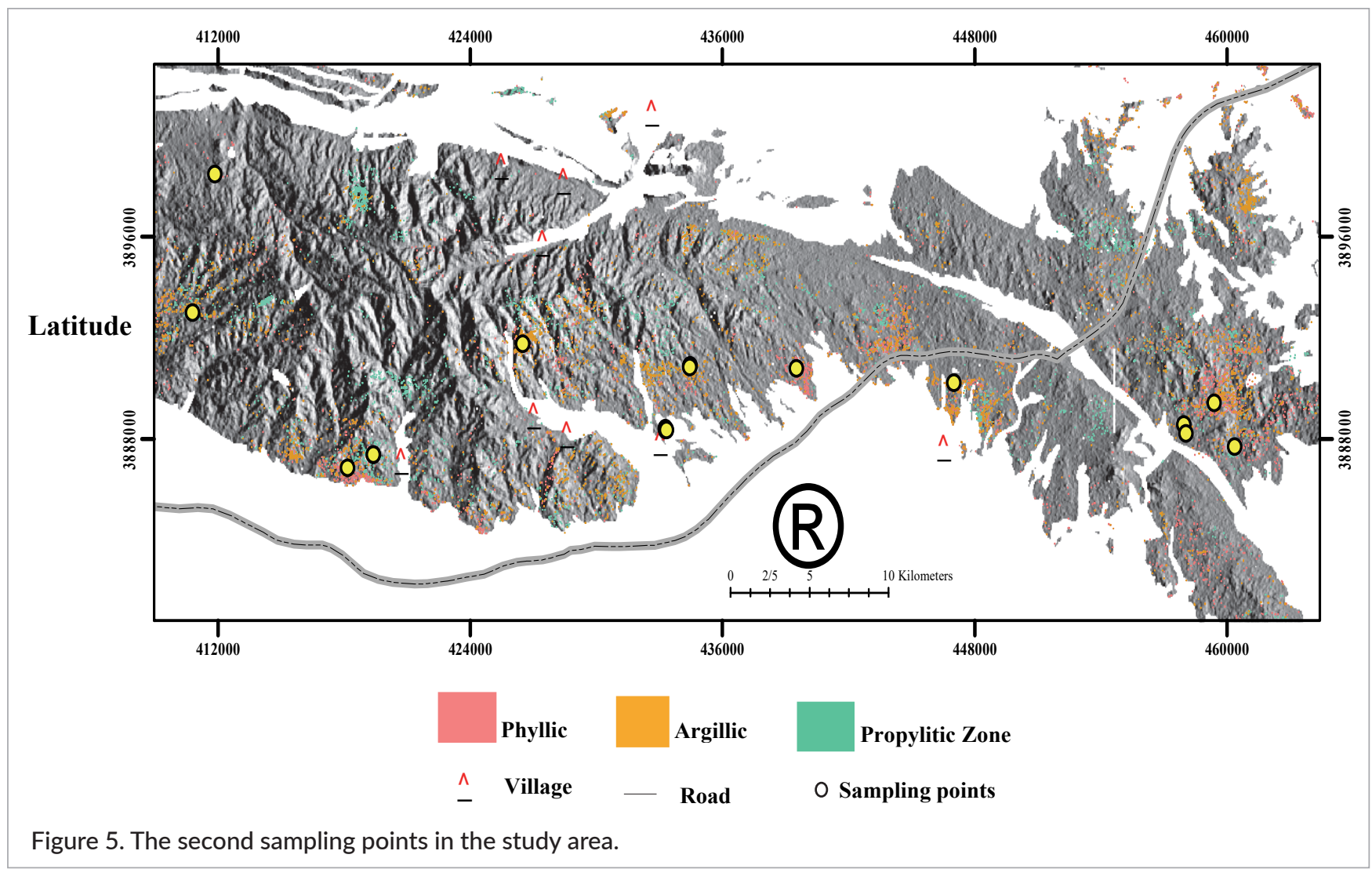

phyllic and argillic alteration. Samples for spectroscopy were collected from these alterations and from chlorite porphyry andesite rocks in the area. Other collected samples were porphyry andesite. These samples spectrum was used by the MTMF method to identify alterations in the region. The second sampling was performed on 21 April 2017 to evaluate the classification results (Figure 5). This sampling showed that rock outcrops in the study area are andesite, basaltic, basaltic andesite, granite, granodiorite and tuff.

\section{Spectral analysis}

Spectral curves created by FieldSpec $3^{\circledR}$ underwent rigorous analyses using TSG software. Figure 6 presents the flowchart of this study. In this flowchart, continuum removal normalises the studied spectra, therefore, the values will be set between 0 and 1 for easier comparison. The continuum is a convex hull fitted to a curve between two endpoints of it. The software could identify mineral groups such as the mica group (illite, muscovite, phengite and paragonite), kaolinite [well-crystallised kaolinite (wx), poorly crystallised kaolinite (px)], amphibole and chlorides (Fe-chlorites and Fe-Mg chlorites) (Figure 7).
Illite $\left\{\mathrm{K}_{2-x} \mathrm{Al}_{4}\left(\mathrm{Si}_{6+x} \mathrm{Al}_{2-x}\right) \mathrm{O}_{20}(\mathrm{OH})_{4}\right\}$, phengite $\left\{\mathrm{K}_{2}(\mathrm{Al}, \mathrm{Mg}, \mathrm{Fe})_{4}\left(\mathrm{Si}_{6+x}, \mathrm{Al}_{2-x}\right) \mathrm{O}_{20}(\mathrm{OH})_{4}\right\}$, muscovite $\left\{\mathrm{K}_{2} \mathrm{Al}_{4}\left(\mathrm{Si}_{6} \mathrm{Al}_{2}\right) \mathrm{O}_{20}(\mathrm{OH})_{4}\right\}$ and paragonite minerals $\left\{\mathrm{Na}_{2} \mathrm{Al}_{4}\left(\mathrm{Si}_{6} \mathrm{Al}_{2}\right) \mathrm{O}_{20}(\mathrm{OH})_{4}\right\}$ (TSG, version 7.1) of the phyllic zone show absorptions with respect to the elements in their composition. ${ }^{61,62}$ Major distinguishing features of illite are absorptions near 1409 nm, 1904 nm, 2203 nm and $2341 \mathrm{~nm}$. The spectrum of phengite absorption features developed near $1414 \mathrm{~nm}, 1911 \mathrm{~nm}, 2205 \mathrm{~nm}$ and $2348 \mathrm{~nm}$ (Figure 7a). Muscovite features are similar to those of illite, but with less well-developed water bands. Distinctive features are sharp absorptions near $1412 \mathrm{~nm}, 1914 \mathrm{~nm}, 2201 \mathrm{~nm}, 2334 \mathrm{~nm}$ (Figure 7b). The paragonite spectrum is similar to muscovite spectra, with absorption features developed near $1410 \mathrm{~nm}, 1914 \mathrm{~nm}$, $2205 \mathrm{~nm}$ and $2345 \mathrm{~nm}$ (Figure 7c).

The kaolinite $\left\{\mathrm{Al}_{2} \mathrm{Si}_{2} \mathrm{O}_{5}(\mathrm{OH})_{4}\right\}$ (TSG, version 7.1) spectrum has absorptions developed near $1400 \mathrm{~nm}, 1912 \mathrm{~nm}$, 2170-2210 nm, $2320 \mathrm{~nm}$ and 2334-2380 nm (Figure 7d).

Montmorillonite $\left\{(\mathrm{Ca}, \mathrm{Na})_{0.67} \mathrm{Al}_{4}(\mathrm{Si}, \mathrm{Al})_{8} \mathrm{O}_{20}(\mathrm{OH})_{4}\right.$. $n \mathrm{H}_{2} \mathrm{O}$ \} (TSG, version 7.1) contains absorption peaks near $2206 \mathrm{~nm}, 2340 \mathrm{~nm}, 1411 \mathrm{~nm}$ and $1908 \mathrm{~nm}$. Because of intense water absorption, both of the 


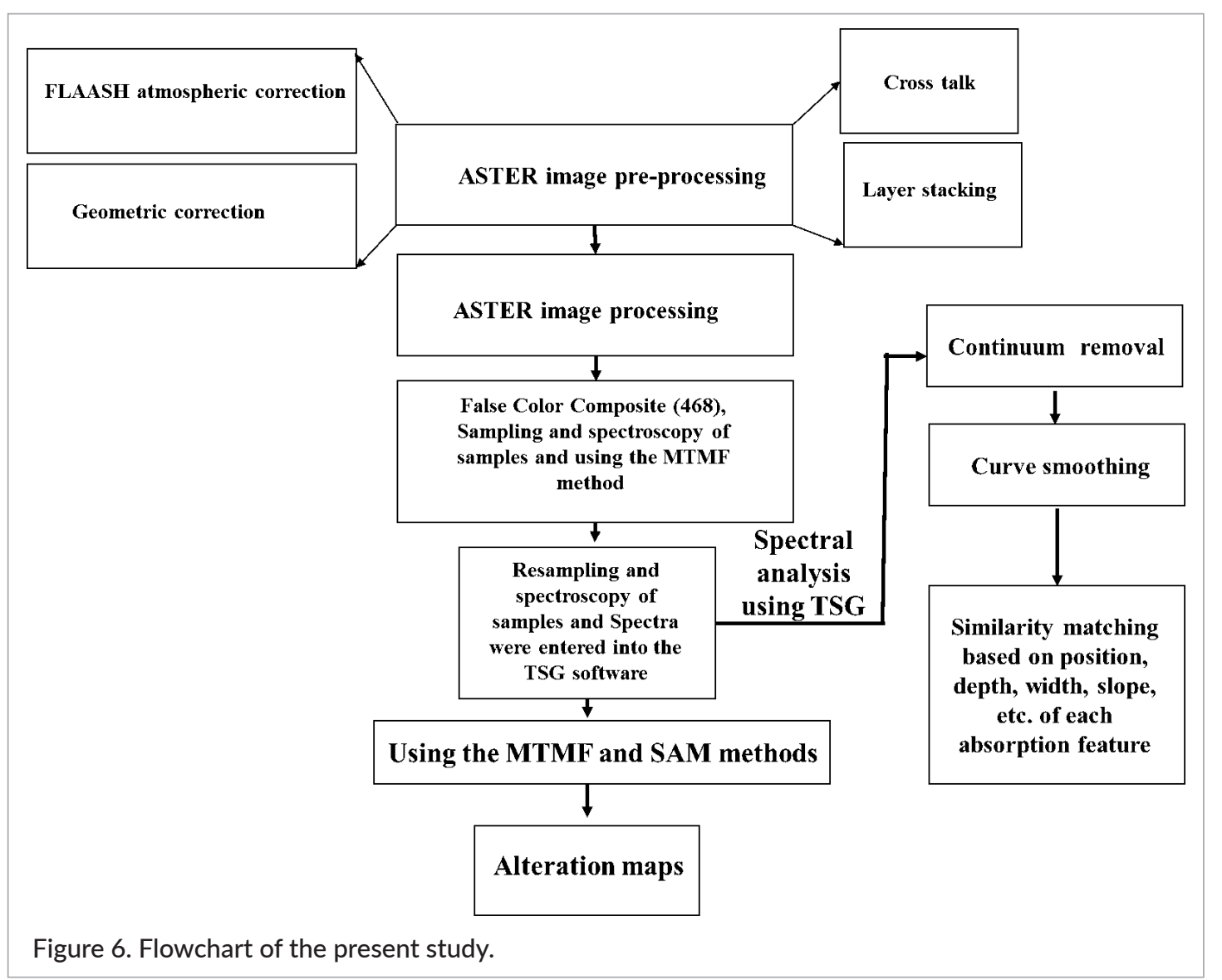

$1411 \mathrm{~nm}$ and $1908 \mathrm{~nm}$ features show an asymmetric curve (Figure 7e).

Hornblende $\left\{(\mathrm{Ca}, \mathrm{Na}, \mathrm{K})_{2-3}(\mathrm{Mg}, \mathrm{Fe}, \mathrm{Al})_{5} \mathrm{Si}_{6}(\mathrm{Si}, \mathrm{Al})_{2} \mathrm{O}_{22}\right.$ $\left.(\mathrm{OH}, \mathrm{F})_{2}\right\}$ displays features near $1405 \mathrm{~nm}, 1910 \mathrm{~nm}$, 2180-2250 nm, $2320 \mathrm{~nm}$ and $2380 \mathrm{~nm}$ (Figure 7f).

Chlorite $\left\{(\mathrm{Mg}, \mathrm{Al}, \mathrm{Fe})_{12}\left[(\mathrm{Si}, \mathrm{Al})_{8} \mathrm{O}_{20}\right](\mathrm{OH})_{16}\right\}(\mathrm{TSG}$, version 7.1) shows two major absorption features at $2180 \mathrm{~nm}$ and $2250-2260 \mathrm{~nm}$ for Fe-chlorite or 2330-2355 nm for $\mathrm{Mg}$-chlorite. Other important features are those near $1409 \mathrm{~nm}$ and $1912 \mathrm{~nm}$ (Figure 7g). Figures 8 and 9 show several rock samples and their spectra and Table 1 present common alteration minerals and their series of spectral absorption that can be measured with spectroradiometry techniques.

In summary, absorption features of the mica group (illite, muscovite, phengite and paragonite), kaolins [well-crystallised kaolinite $(w x)$, poorly crystallised kaolinite $(p x)$ ], amphibole and chlorites minerals (Fe, Fe-Mg chlorites) may depict the presence of $\mathrm{H}_{2} \mathrm{O}$ and $\mathrm{OH}$ molecules which may indicate changes due to hydrothermal alteration.

After sampling and measuring the spectra, the distributions of kaolinite and montmorillonite (argillic), illite, muscovite, phengite and paragonite (phyllic), hornblende, and chlorite (propylitic) were mapped using SAM and MTMF algorithms.

The concentration of the phyllic, argillic and propylitic zones is enhanced by the SAM and MTMF algorithms. However, when the phyllic zone is enhanced by the SAM algorithm, it appears to be more extensive than when the MTMF algorithm is used, whereas the argillic zone depicted by the MTMF algorithm appears to be larger than that indicated by the SAM algorithm. However, the results of the propylitic zone distribution are similar in SAM and MTMF algorithms. Figures 10 and 11 show the results of the detection of phyllic, argillic and propylitic alteration zones by the SAM and MTMF methods.

The alteration zones recognised by the SAM and MTMF methods were examined in the field. In terms of examining the zones detected by the algorithms, another field sampling was carried out. The sampling showed that each zone detected by the algorithms was correct. An extensive range of igneous rock types (diorite to granodiorite and granite) are spatially associated with porphyry deposits as suggested by Richards ${ }^{63}$ in this study area. In the Saveh 

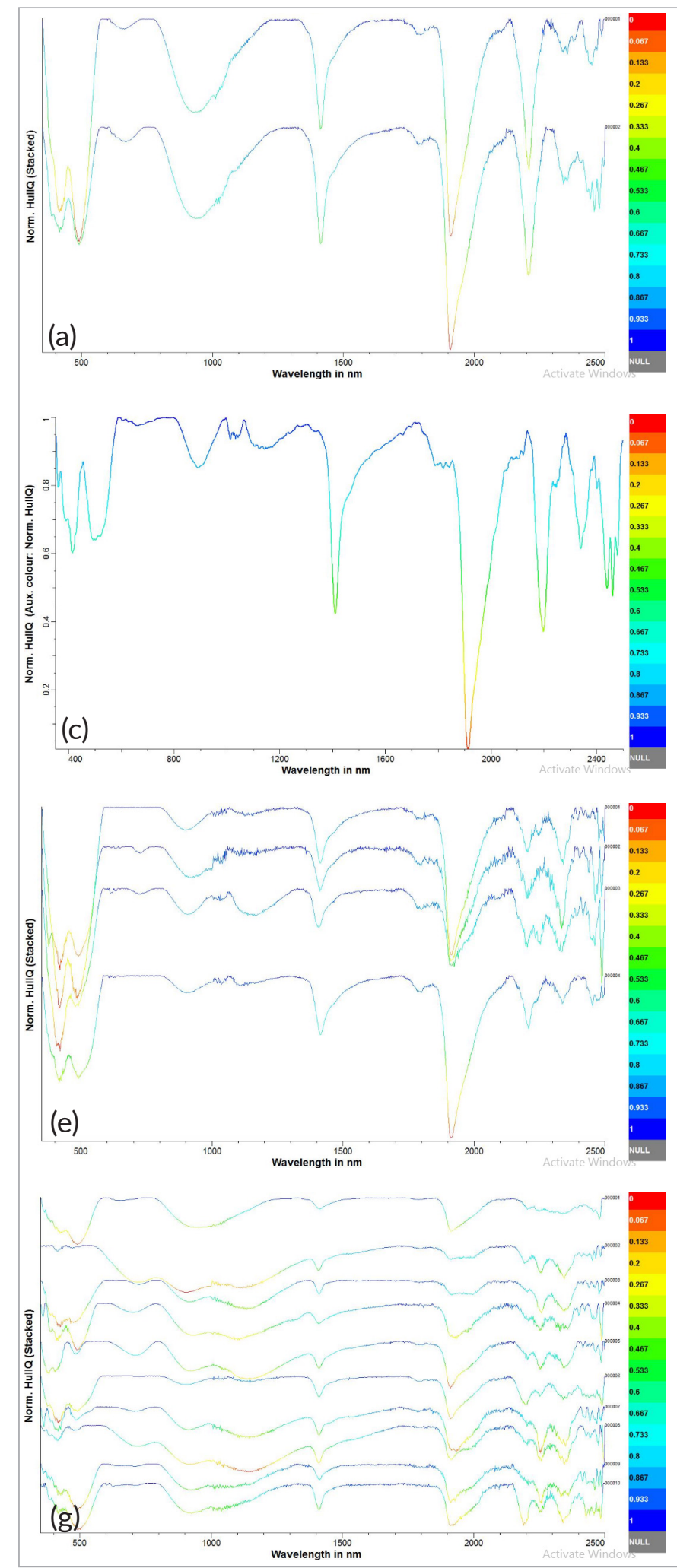

area, the phyllic alteration zone mostly occurs along granodiorite and granite igneous rocks, and in some areas, it is also visible on the tuff and andesitic lava, whereas the argillic and propylitic alteration zones are often associated
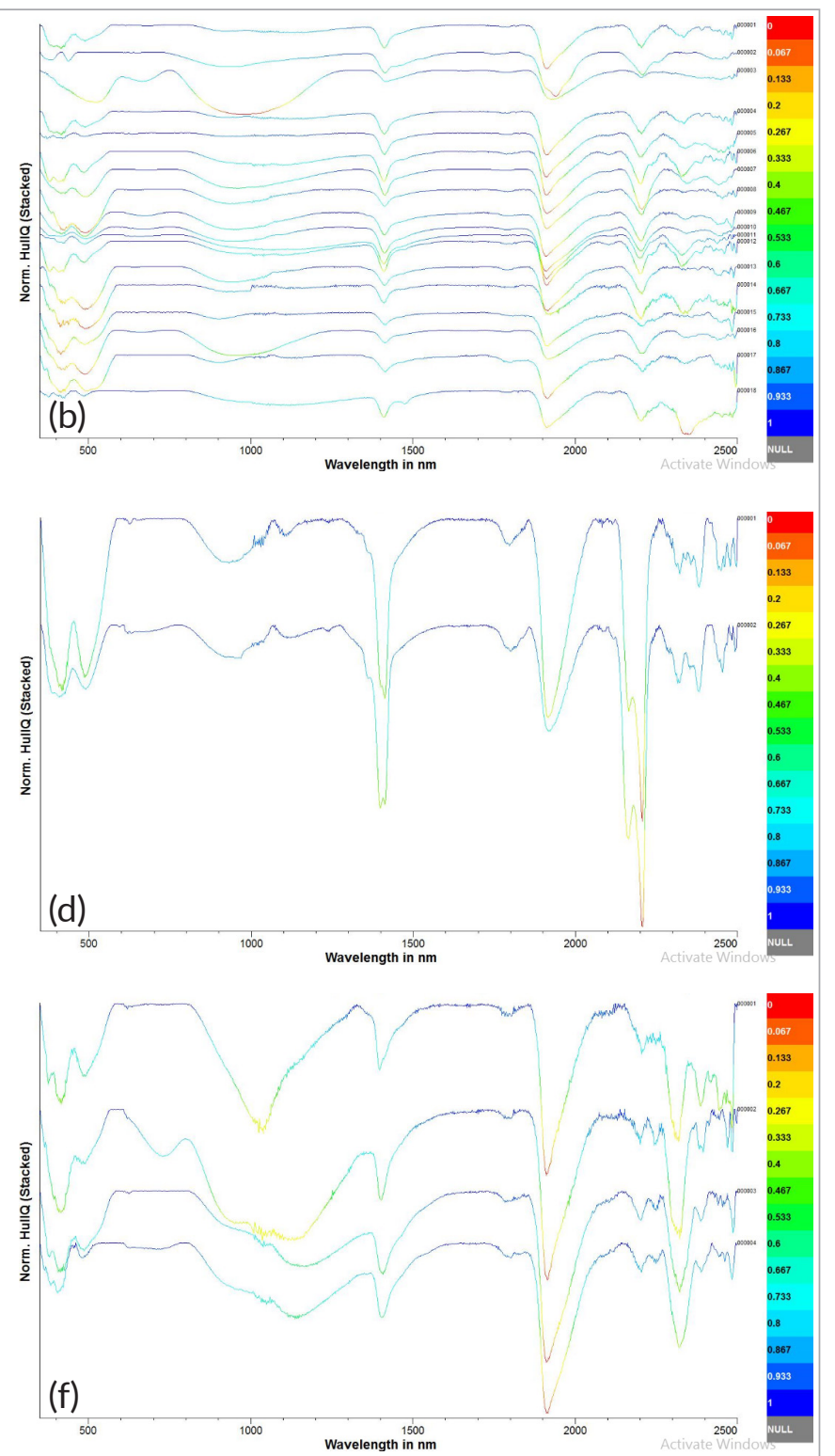

Figure 7. Comparative analysis between the spectra of the target minerals examined using TSG software of the study area samples: (a) illite-phengite, (b) muscovite, (c) paragonite, (d) kaolinite, (e) montmorillonite, (f) hornblende and (g) chlorite (the error value for the match between the TSG library samples and the studied samples is shown as a colour bar next to each figure above. 1 indicates a perfect match and 0 indicates no match).

with the tuff and andesitic lava and in some areas the argillic and propylitic alteration zones also visible on the granodiorite rocks. The results of the two methods are very similar but the MTMF method is a little more appropriate. 

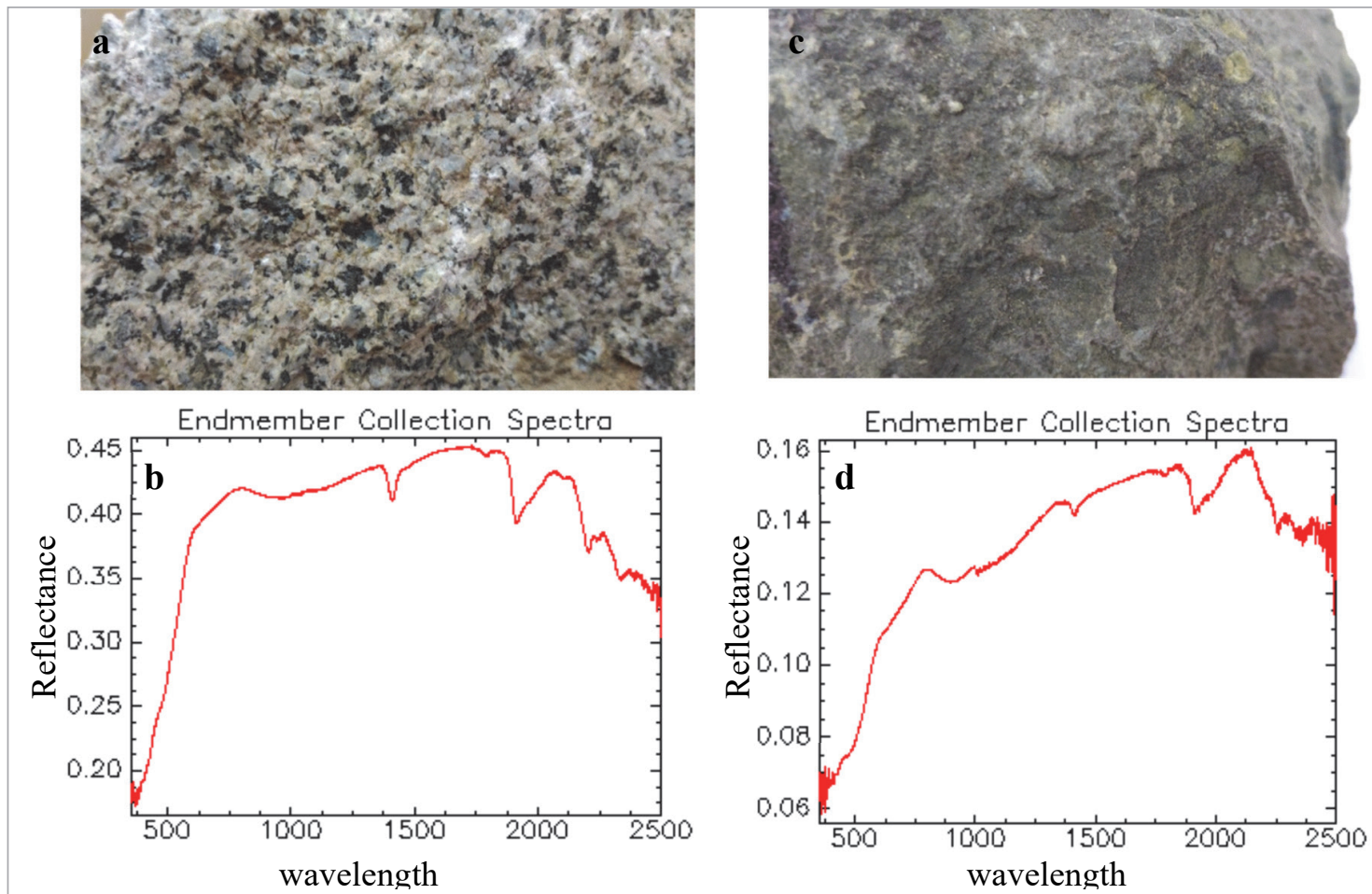

Figure 8. (a) Granite rock sample, (b) the spectrum of muscovite-illite, obtained from granite rock sample, (c) basaltic rock sample and (d) the spectrum of chlorite Fe obtained from a basaltic rock sample. In (b) and (d) the vertical axis contains the reflectance values and the horizontal axis contains wavelength values (nm).

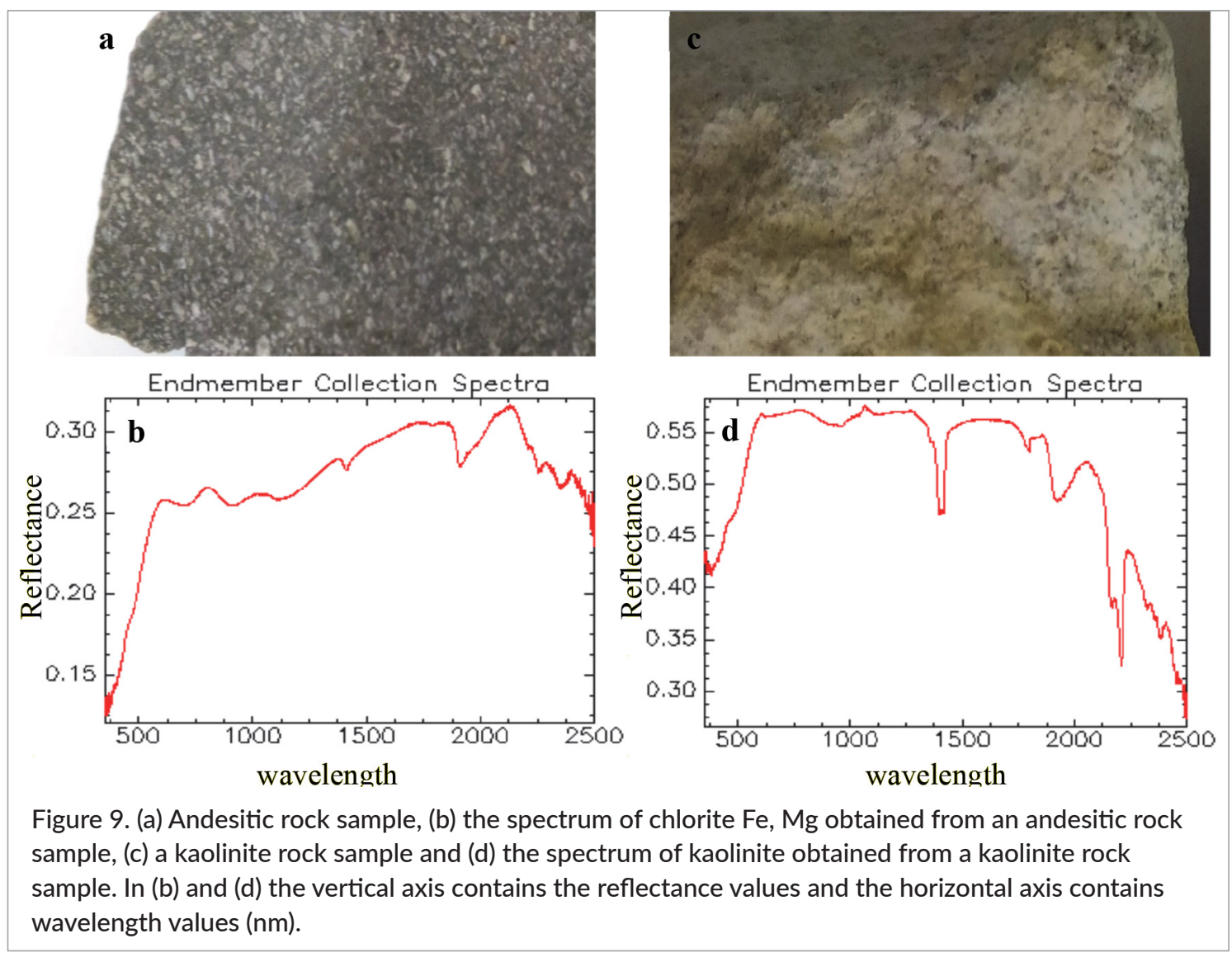


Table 1. Common alteration minerals measured with spectroradiometric technique in the study area and their range of spectral absorption.

\begin{tabular}{|c|c|c|c|c|c|c|c|}
\hline Mineral type & $\begin{array}{c}\mathrm{OH} \& \mathrm{H}_{2} \mathrm{O} \\
=1400 \mathrm{~nm}, \\
\mathrm{H}_{2} \mathrm{O}= \\
1900 \mathrm{~nm}\end{array}$ & $\begin{array}{c}\mathrm{AlOH}=2190- \\
2220 \mathrm{~nm}\end{array}$ & $\begin{array}{c}\mathrm{MgOH}=2310- \\
2360 \mathrm{~nm}\end{array}$ & $\begin{array}{l}\mathrm{CaCO}_{3}= \\
2350 \mathrm{~nm}\end{array}$ & $\begin{array}{c}\mathrm{K}=630- \\
740 \mathrm{~nm}\end{array}$ & $\begin{array}{c}\mathrm{Fe}= \\
900 \mathrm{~nm}\end{array}$ & $\begin{array}{c}\mathrm{Na}= \\
580 \mathrm{~nm}\end{array}$ \\
\hline Muscovite & $*$ & $*$ & - & - & * & - & - \\
\hline Illite & * & $*$ & - & - & * & - & - \\
\hline Phengite & $*$ & * & * & - & * & $*$ & - \\
\hline Paragonite & * & * & - & - & - & - & * \\
\hline Kaolinite & * & * & - & - & - & - & - \\
\hline Montmorillonite & $*$ & $*$ & - & $*$ & - & - & * \\
\hline Hornblende & * & * & - & * & * & * & * \\
\hline Chlorite & $*$ & $*$ & * & - & - & * & - \\
\hline
\end{tabular}

*Present, - not present

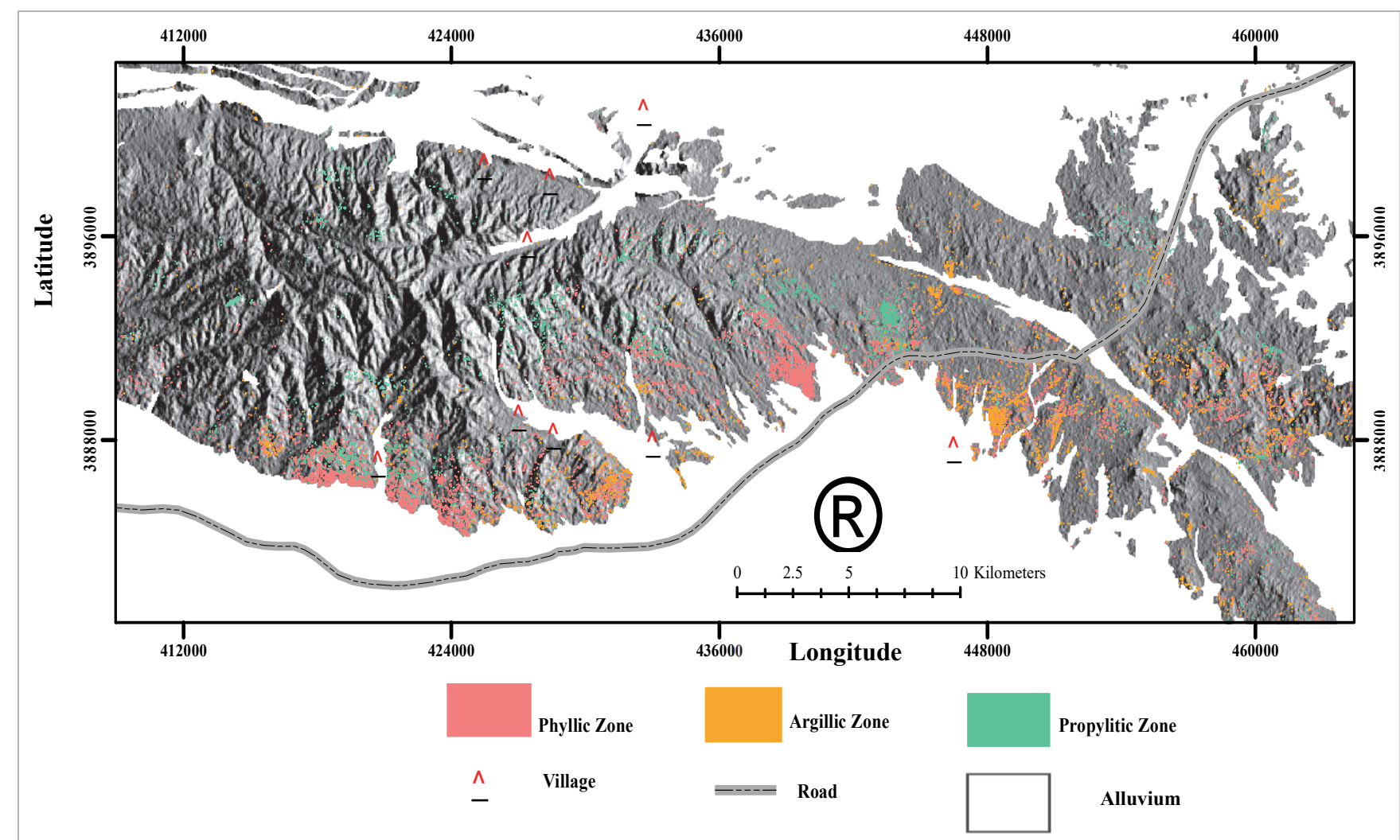

Figure 10. Spatial distribution of phyllic, agillic and propylitic hydrothermally altered zones, as estimated by the SAM algorithm, north of Saveh, Iran.

\section{The spectroradiometric technique's results}

Samples have been collected from the common areas of each zone obtained by both algorithms. The sampling points are displayed in Figure 5. Then, to verify the results of the SAM and MTMF methods, each rock sample was examined with a FieldSpec $3^{\circledR}$ spectrometer and with TSG software.

The TSA of the TSG software, having important minerals among the 60 classes in the current library has an extraordinary ability to detect minerals. When the spectrum 


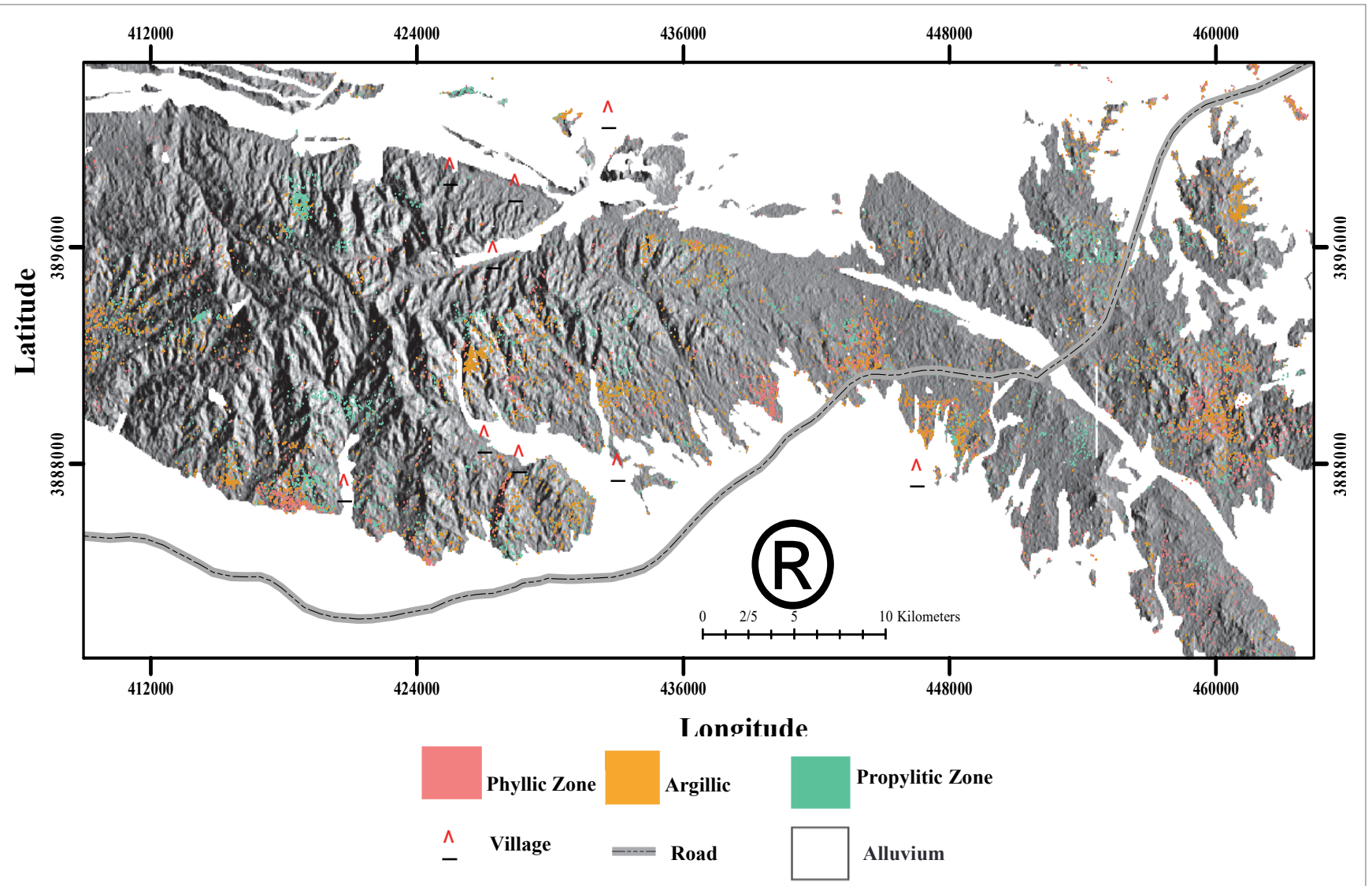

Figure 11. Spatial distribution of phyllic, argillic and propylitic hydrothermally altered zones as estimated by the MTMF algorithm, north of Saveh, Iran.

enters the TSG software, the software compares these spectra based on their absorption points (depth, position, width, slope etc.) with its library spectra and, therefore, it can identify the desired mineral. The similarity matching is based on calculating the correlation between two spectra. Figure 12 shows the percentage of identified mineral groups of the study area using TSG software which is evidence of the TSG's ability to detect minerals. The mica group (illite, muscovite, phengite and paragonite) have their main absorption at about $1400 \mathrm{~nm}$ and 2200 nm (Figure 7a). Kaolinites [well-crystallised kaolinite (wx), poorly crystallised kaolinite (px), dickite and nacrite] have "doublet" absorption features at around $1400 \mathrm{~nm}$ and $2170 \mathrm{~nm}$. Unlike the mica group, all the kaolinites have the same chemical formula $\left[\mathrm{Al}_{4} \mathrm{Si}_{4} \mathrm{O}_{10}(\mathrm{OH})_{8}\right]$ (Figure 7b). The two small absorption features at about $2250 \mathrm{~nm}$ and $2350 \mathrm{~nm}$ taken together are diagnostic of chlorite features (Table 1) and the general chemical formula for chlorite is (Fe; $\mathrm{Mg} ; \mathrm{Al})_{12}(\mathrm{Si} ; \mathrm{Al})_{8} \mathrm{O}_{20}(\mathrm{OH})_{16}(\mathrm{Fe} ; \mathrm{Mg} ; \mathrm{Al})_{12}$. As the $\mathrm{Mg}$ number increases, the positions of both of these features tend to decrease. The TSA software routine distinguishes the mineral types according to the shapes of these absorption features. To determine the type of minerals, all the samples spectra were entered into the TSG software and the results are displayed in Table 2.

The areas detected by the MTMF method were examined and sampling was performed on those areas. Then the spectrum of rock samples was obtained using a spectrometer and entered into the TSG software in order to detect rock samples correctly. The results showed that TSG is well able to detect minerals and this software confirms the results of the MTMF method. The results also showed that the MTMF is capable of detecting the studied minerals (Table 2).

Based on the spectroscopy tools (FieldSpec $3^{\circledR}$ and TSG software), prominent minerals such as illite, muscovite, phengite, paragonite, kaolinite, montmorillonite, hornblende, chlorite, gypsum, siderite, hematite and goethite are found in the study area. As previously stated, the TSG searches the similarities between the imported samples and the spectral library and it detects the percentage of minerals presented in the studied samples. Based on this, the percentage of minerals is displayed in different colours. According to Figure 12, it can be seen that the 
Table 2. The identified minerals of the study area by TSG software.

\begin{tabular}{|c|c|c|c|}
\hline Rock samples & TSG results & Rock samples & TSG results \\
\hline Acidic tuff & Muscovite, illite, goethite & Dacitic & Chlorite Fe, paragonite \\
\hline Acidic tuff & $\begin{array}{l}\text { Muscovite, illite, montmoril- } \\
\text { lonite, goethite }\end{array}$ & Dacitic & Paragonite \\
\hline Acidic tuff & $\begin{array}{l}\text { Muscovite, illite, montmoril- } \\
\text { lonite, goethite }\end{array}$ & Ferric sample & Siderite, goethite \\
\hline Acidic tuff & Muscovite, goethite & Ferric sample & Siderite, kaolinite $(P x)$, goethite \\
\hline Acidic tuff & Muscovite, illite, goethite & Granite & Muscovite \\
\hline Acidic tuff & Muscovite, illite, kaolinite (Px) & Granite & Illite, chlorite-Mg, goethite \\
\hline Andesitic & Muscovite, goethite & Granite & $\begin{array}{l}\text { Muscovite, illite, montmoril- } \\
\text { lonite }\end{array}$ \\
\hline Andesitic & Siderite, montmorillonite & Granite & Muscovite, goethite \\
\hline Andesitic & Chlorite-Mg, goethite & Granite & $\begin{array}{l}\text { Muscovite, illite, siderite, goe- } \\
\text { thite }\end{array}$ \\
\hline Andesitic & Chlorite-Mg, goethite & Granite & Muscovite, illite \\
\hline Andesitic & $\begin{array}{l}\text { Muscovite, montmorillonite, } \\
\text { goethite }\end{array}$ & Granite & $\begin{array}{l}\text { Siderite, montmorillonite, } \\
\text { goethite }\end{array}$ \\
\hline Andesitic & Siderite, montmorillonite & Granite & $\begin{array}{l}\text { Siderite, montmorillonite, } \\
\text { goethite }\end{array}$ \\
\hline Andesitic & $\begin{array}{l}\text { Siderite, montmorillonite, } \\
\text { goethite }\end{array}$ & Granite & Illite, kaolinite (Px), goethite \\
\hline Andesitic & Siderite, montmorillonite & Granite & Siderite, montmorillonite \\
\hline Andesitic-basaltic & Chlorite Fe & Granite & Paragonite, chlorite Fe-Mg \\
\hline Andesitic-basaltic & $\begin{array}{l}\text { Illite, montmorillonite, goe- } \\
\text { thite }\end{array}$ & Hornblende andesitic & $\begin{array}{l}\text { Hornblende, kaolinite (Px), } \\
\text { goethite }\end{array}$ \\
\hline Andesitic-basaltic & Chlorite Fe-Mg & Hornblende andesitic & Hornblende, epidote, goethite \\
\hline Andesitic-basaltic & Chlorite Fe-Mg, muscovite & Hornblende andesitic & $\begin{array}{l}\text { Hornblende, chlorite-Mg, } \\
\text { goethite }\end{array}$ \\
\hline Andesitic-basaltic & Chlorite Fe & Kaolinite sample & Muscovite, kaolinite $(\mathrm{Wx})$ \\
\hline Andesitic-basaltic & Chlorite Fe, paragonite & Kaolinite sample & Kaolinite (Px) \\
\hline Andesitic-basaltic & Phengite, siderite, goethite & Kaolinite sample & Muscovite, gypsum \\
\hline Andesitic-basaltic & Siderite, muscovite, goethite & Kaolinite sample & Kaolinite (Px), goethite \\
\hline Andesitic-basaltic & $\begin{array}{l}\text { Chlorite Fe-Mg, montmoril- } \\
\text { lonite }\end{array}$ & Kaolinite sample & Kaolinite $(P x)$, hematite \\
\hline Basaltic & Chlorite Fe-Mg, muscovite & Kaolinite sample & Kaolinite $(W x)$, goethite \\
\hline Basaltic & Chlorite Fe, paragonite & Kaolinite sample & Kaolinite (Wx) \\
\hline Basaltic & Chlorite Fe, paragonite & Kaolinite sample & Kaolinite $(\mathrm{W} x)$, goethite \\
\hline Basaltic & Siderite, muscovite, goethite & Kaolinite sample & Kaolinite (Px) \\
\hline Basaltic & Phengite, goethite, siderite & Kaolinite sample & Kaolinite $(\mathrm{W} x)$, goethite \\
\hline Basaltic & $\begin{array}{l}\text { Siderite, montmorillonite, } \\
\text { goethite }\end{array}$ & Pyroclastic sample & Chlorite Fe, goethite \\
\hline Basaltic & $\begin{array}{l}\text { Chlorite Fe-Mg, kaolinite (Px), } \\
\text { goethite }\end{array}$ & & \\
\hline
\end{tabular}




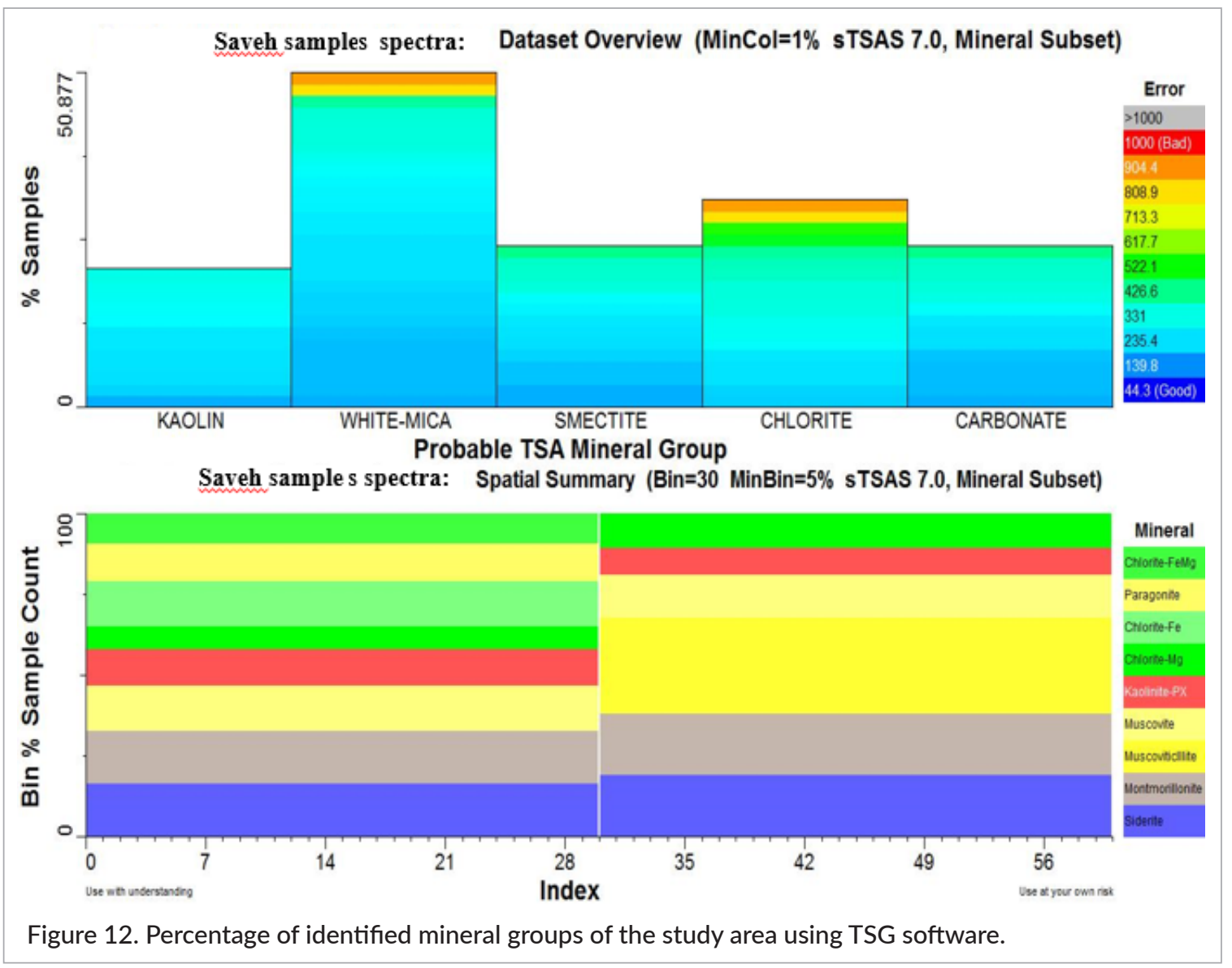

percentage of muscovite and illite minerals was higher than other minerals. Also, mineral groups are well detected in the samples by TSG.

Detection of the types of the mica group, kaolinite and chlorite minerals is one of the most important features using TSG software. The iron minerals of goethite, hematite and siderite could be recognised by TSG. The identification of each mineral depends on the amount (depth) of the absorption and wavelength position it imposes on the spectral curve. Because the TSG procedure for mineral identification is based on the spectral curve matching of the minerals and that of the software spectral data bank, therefore, the advantage of this software is that it also can indicate any amount of concentration of the minerals.

\section{Conclusions}

The vast and complex geological setting in the Iranian Saveh area needs cutting-edge technology to be implemented for the exploration and development of new promising mineral potential zones. Therefore, the present study presents the combined use of spectroradiometry measurements and remote sensing data processing. In order to classify the satellite image, the procedure is that the ground samples are spectroscopically determined, then their spectrum is used as a reference spectrum for the implementation of the SAM and MTMF methods based on using ASTER satellite images. The results exhibit that the simultaneous use of these technologies could enhance fast and accurate zones of mineral potential. Different kinds of minerals such as illite, muscovite, phengite, paragonite, kaolinite, montmorillonite, hornblende, chlorite, gypsum, hematite, siderite and goethite have been identified for further detailed geochemical analysis. Based on field spectral data and their assimilation with ASTER satellite data, calibration and classification were carried out to make a clear distribution of minerals in the study area as has been shown in the present text. Because the TSG procedure for mineral identification is based on the spectral curve matching of the minerals and that of the software spectral data bank, the advantage of this software is that it also can indicate 
any amount of concentration of the minerals. Finally, it is concluded that the area has undergone a different level of hydrothermal alteration so much so that phyllic, argillic and propylitic types of minerals are present in the study area. It should be noted that for the first time the study area has been investigated from a different view angle, i.e. in addition to spectral data bank creation and utilisation of specialised TSG software, a synoptic satellite view was used to see the whole complex simultaneously and analyse the relationship of the different rocks. It is vital to note that porphyry copper systems are centred within a distinct shell of hydrothermally altered rocks including sodic-calcic, potassic, chlorite-sericite, sericitic and finally near-surface advanced argillic, e.g. Sillitoe. ${ }^{64}$ Notably, in most cases, the erosion may lead to the surficial exposure of all alterations. Although there are many key factors in the exploration of porphyry deposits, the fact is that the alterations are one of the most vital signals in the exploration of porphyry copper systems. Accordingly, the findings of the present work could be complementary to the future exploratory works in the area and maybe other porphyry-bearing belts.

\section{Acknowledgement}

This investigation was carried out using university grant No. 97.3.02.26247 dated 10/07/2018 for which the authors are thankful to the vice-chancellor of research, Shahid Chamran University of Ahvaz-Iran.

\section{References}

1. G.R. Hunt and J.W. Salisbury, "Visible and near-infrared spectra of minerals and rocks: XII. Metamorphic rocks", Mod. Geol. 5, 219-228 (1976).

2. M.J. Abrams, D. Brown, L. Lepley and R. Sadowski, "Remote sensing of porphyry copper deposits in Southern Arizona", Econ. Geol. 78, 591-604 (1983). https://doi.org/10.2113/gsecongeo.78.4.591

3. D.M. Spatz and R.T. Wilson, "Remote sensing characteristics of porphyry copper systems, western America Cordillera", in Arizona Geological Society Digest, Ed by F.W. Pierce and J.G. Bolm. Vol. 20, pp. 94-108 (1995).

4. J.W. Salisbury, L.S. Walter, N. Vergo and D.M. D'Aria, Infrared (2.1-25 micrometers) Spectra of Minerals.
Johns Hopkins University Press, Baltimore, Maryland, USA (1991).

5. A. Kerr, H. Rafuse, G. Sparkes, J. Hinchey and H. Sandeman, "Visible/infrared spectroscopy (VIRS) as a research tool in economic geology; background and pilot studies from New Foundland and Labrador", Geol. Surv. 11(1), 145-166 (2011).

6. K. Rangzan, A. Saki, A. Saberi and H. Hassan Shahi., "Identification of aluminosilicate polymorph $\left(\mathrm{Al}_{2} \mathrm{SiO}_{5}\right)$ using software in Hamedan region", Iranian Remote Sens. GIS 2(4), 57-70 (2011) (in Persian).

7. K. Rangzan, A. Saki, H. Hassan Shahi and B. Mojaradi, "Analysis and spectral classification of igneous and metamorphic rocks in the Hamedan region for remote sensing studies using reflectance spectroscopy (350 to 2500 nm)", Crystallography Mineralogy Iran. pp. 81-96 (2012) (in Persian).

8. H. Pourkaseb, K. Demiri, K. Rangzan and S. Saedi, "Enhancing of the World's Salt Dome (Firoozabat, Iran), using principal component analysis", Econ. Geol. 5(1), 83-92 (2013) (in Persian).

9. M. Karami, K. Rangzan and A. Sabari, "Using GIS servers and interactive maps in spectral data sharing and administration: Case study of Ahvaz Spectral Geodatabase Platform (ASGP)", Comput. Geosci. 60, 23-33 (2013). https://doi.org/10.1016/j. cageo.2013.06.007

10. B. Agar and D. Coulter, "Remote sensing for mineral exploration a decade perspective 1997-2007", in Proceedings of Exploration 07: Fifth Decennial International Conference on Mineral Exploration, Ed by B. Milkereit, pp. 109-136 (2007).

11. Massironi, L. Bertoldi, P. Calafa, D. Visona, A. Bistacchi, C. Giardina and A. Schiavo, "Interpretation and processing of ASTER data for geological mapping and granitoids detection in the Saghro massif (eastern Anti-Atlas, Morocco)", Geosphere 4(4), $736-$ 759 (2008). https://doi.org/10.1130/GES00161.1

12. J.C. Mars and L.C. Rowan, "Spectral assessment of new ASTER SWIR surface reflectance data products for spectroscopic mapping of rocks and minerals", Remote Sens. Environ. 114, 2011-2025 (2010). https://doi.org/10.1016/j.rse.2010.04.008

13. M. Honarmand, H. Ranjbar and J. Shahabpour, "Application of spectral analysis in mapping hydrothermal alteration of the northwestern part of the Kerman Cenozoic Magmatic Arc, Iran", J. Sci. Iran 22(3), 221-238 (2011). 
14. M. Khaleghi, H. Ranjbar, J. Shahabpour and M. Honarmand, "Spectral angle mapping, spectral information divergence, and principal component analysis of the ASTER SWIR data for exploration of porphyry copper mineralization in the Sarduiyeh area, Kerman province, Iran", Appl. Geomat. 6, 49-58 (2014). https://doi.org/10.1007/s12518-014-0125-0

15. L. Liu, J. Zhou, L. Han and X. Xu, "Mineral mapping and ore prospecting using Landsat TM and Hyperion data, Wushitala, Xinjiang, northwestern China", Ore Geol. Rev. 81, 280-295 (2017). https:// doi.org/10.1016/j.oregeorev.2016.10.007

16. S.J. Yousefi, H. Ranjbar, S. Alirezaei, S. Dargahi and L.R. Lentz, "Comparison of hydrothermal alteration patterns associated with porphyry Cu deposits hosted by granitoids and intermediate-mafic volcanic rocks, Kerman Magmatic Arc, Iran: Application of geological, mineralogical and remote sensing data", J. Afr. Earth Sci. 142, 112-123 (2018). https://doi. org/10.1016/j.jafrearsci.2018.03.005

17. H. Azizi, M.A. Tarverdi and A. Akbarpour, "Extraction of hydrothermal alterations from ASTER SWIR data from east Zanjan, northern Iran", Adv. Space Res. 46, 99-109 (2010). https://doi. org/10.1016/j.asr.2010.03.014

18. M. Honarmand, H. Ranjbar and J. Shahabpour, "Application of principal component analysis and spectral angle mapper in the mapping of hydrothermal alteration in the Jebal-Barez Area, southeastern Iran", Resour. Geol. 62(2), 119-139 (2012). https://doi. org/10.1111/j.1751-3928.2012.00184.x

19. R. Amer, A. El Mezayen and M. Hasanein, "ASTER spectral analysis for alteration minerals associated with gold mineralization", Ore Geol. Rev. 75, 239-251 (2016). https://doi.org/10.1016/j.oregeorev.2015.12.008

20. J.W. Boardman, F.A. Kruse and R.O. Green, "Mapping target signatures via partial unmixing of AVIRIS data", Summaries of the Fifth JPL Airborne Earth Science Workshop. JPL Publication, Vol. 1, pp. 23-26 (1995).

21. A. Beiranvand Pour and M. Hashem, "The application of ASTER remote sensing data to porphyry copper and epithermal gold deposits", Ore Geol. Rev. 44, 1-9 (2012). https://doi.org/10.1016/j.oregeorev.2011.09.009

22. J. Ghalamghash, 1:100,000 Geological Map of Saveh. Geological Survey of Iran (1998).
23. G.R. Hunt and P. Ashley, "Spectra of altered rocks in the visible and near-infrared", Econ. Geol. 74, 1613-1629 (1979). https://doi.org/10.2113/gsecongeo.74.7.1613

24. G. Ferrier, K. White, G. Griffiths, R. Bryant and M. Stefouli, "The mapping of hydrothermal alteration zones on the island of Lesvos, Greece, using an integrated remote sensing dataset", Int. J. Remote. Sens. 23, 341-356 (2002). https://doi. org/10.1080/01431160010003857

25. J.D. Lowell and J.M. Guilbert, "Lateral and vertical alteration-mineralization zoning in porphyry ore deposits", Econ. Geol. 65, 373-408 (1970). https:// doi.org/10.2113/gsecongeo.65.4.373

26. K. Rangzan, Structure and Tectonics of Zagros Structural Belt, SW Iran. Unpublished PhD Thesis, Aligarh Muslim University, Aligarh, India (1993).

27. N. Ilbeyli, J.A. Pearce, M.F. Thirlwall and J.G. Mitchell, "Petrogenesis of collision-related plutonics in Central Anatolia, Turkey", Lithos 72(3-4), 163-182 (2004). https://doi.org/10.1016/j.lithos.2003.10.001

28. Iqbaluddin and K. Rangzan, "Geological interpretation of Zagros structural belt, Iran and its correlation to Himalayan structural belts", Indian Mineral. 47(4), 287-292 (1993).

29. M. Alavi, "Structures of the Zagros fold-thrust belt in Iran", Am. J. Sci. 307, 1064-1095 (2007). https:// doi.org/10.2475/09.2007.02

30. M. Takin, "Iranian geology and continental drift in the Middle East", Nature 23, 147-150 (1972). https:// doi.org/10.1038/235147a0

31. M. Alavi, "Tectonostratigraphic evolution of Zagrosides of Iran", Geology 8, 144-149 (1980). https://doi.org/10.1130/00917613(1980)8<144:TEOTZO>2.0.CO;2

32. F. Berberian, I.D. Muir, R.J. Pankhurst and M. Berberian, "Late Cretaceous and early Miocene Andean-type plutonic activity in northern Makran and central Iran", J. Geol. Soc. 139, 605-614 (1982). https://doi.org/10.1144/gsjgs.139.5.0605

33. J. Dercourt, L.P. Zonenshain, L.E. Ricou, V.G. Kazmin, X. LePichon, A.L. Knipper, C. Grandjacquet, I.M. Sbortshikov, J. Geyssant, C. Lepvrier, D.H. Pechersky, J. Boulin, J.C. Sibuet, L.A. Savostin, O. Sorokhtin, M. Westphal, M.L. Bazhenov, J.P. Lauer and B. Biju-Duval, "Geological evolution of the Tethys belt from the Atlantic to the Pamirs since the 
Lias", Tectonophysics 123, 241-315 (1986). https:// doi.org/10.1016/0040-1951(86)90199-X

34. A.M.C. Sengor, "Plate tectonics and orogenic research after 25 years: a Tethyan perspective", Earth Sci. Rev. 27, 1-201 (1990). https://doi. org/10.1016/0012-8252(90)90002-D

35. A. Saeedi, A. Maqsoudi and S. Younesi, Geochemical Exploration in Saveh 1:100,000 Sheet. Geological Survey of Iran, Tehran (2013) (in Persian).

36. A. Zarasvandi, M. Rezaei, J.G. Raith, H. Pourkaseb, S. Asadi, M. Saed and D.R. Lentz, "Metal endowment reflected in chemical composition of silicates and sulfides of mineralized porphyry copper systems, Urumieh-Dokhtar magmatic arc, Iran", Geochim. Cosmochim. Acta 223, 36-59 (2018). https://doi. org/10.1016/j.gca.2017.11.012

37. B. Shafiei and J. Shahabpour, "Gold distribution in porphyry copper deposits of Kerman region, southeastern Iran", J. Sci. Islamic Republic Iran 19, 247-260 (2008).

38. A. Hezarkhani and A.E. Williams-Jones, "Controls of alteration and mineralization in the Sungun Porphyry Copper Deposit, Iran: evidence from fluid inclusions and stable isotopes", Econ. Geol. 93, 651-670 (1998). https://doi.org/10.2113/gsecongeo.93.5.651

39. N. Taghipour, A. Aftabi and R. Mathur, "Geology and Re-Os geochronology of mineralization of Miduk porphyry copper deposit, Iran", Resour. Geol. 58(2), 143-160 (2008). https://doi.org/10.1111/j.17513928.2008.00054.x

40. S. Asadi, F. Moore and A. Zarasvandi, "Discriminating productive and barren porphyry copper deposits in the southeastern part of the central Iranian volcano-plutonic belt, Kerman region, Iran: a review", Earth Sci. Rev. 138, 25-46 (2014). https:// doi.org/10.1016/j.earscirev.2014.08.001

41. A. Zarasvandi, M. Rezaei, J.G. Raith, S. Asadi and D.R. Lentz, "Hydrothermal fluid evolution in collisional Miocene porphyry copperdeposits in Iran: Insights into factors controlling metal fertility", Ore Geol. Rev. 105, 183-200 (2019). https://doi. org/10.1016/j.oregeorev.2018.12.027

42. M. Rezaei Kahkhaei, C. Galindo, R.J. Pankhurst and D. Esmaeily, "Magmatic differentiation in the calcalkaline Khalkhab-Neshveh pluton, Central Iran", J. Asian Earth Sci. 42, 499-514 (2011). https://doi. org/10.1016/j.jseaes.2011.04.022
43. A. Iwasaki and H. Tonooka, "Validation of a crosstalk correction algorithm for ASTER/SWIR", IEEE Trans. Geosci. Remote Sens. 43, 2747-2751 (2005). https:// doi.org/10.1109/TGRS.2005.855066

44. L.S. Galvao, R. Almeida-Filho and I. Vitorello, "Spectral discrimination of hydrothermally altered materials using ASTER short-wave infrared bands: evaluation in a tropical savannah environment", Int. J. Appl. Earth Observ. Geoinform. 7(2), 107-114 (2005). https://doi.org/10.1016/j.jag.2004.12.003

45. F.F. Sabins, "Remote sensing for mineral exploration", Ore Geol. Rev. 14(3-4), 157-183 (1999). https://doi. org/10.1016/S0169-1368(99)00007-4

46. A.F.H. Goetz, B.N. Rock and L.C. Rowan, "Remote sensing for exploration: an overview", Econ. Geol. 78, 573-590 (1983). https://doi.org/10.2113/gsecongeo.78.4.573

47. D.H. Knepper, Jr, "Mapping hydrothermal alteration with Landsat Thematic Mapper data", 28th International Geological Congress Guidebook, T182. pp. 13-21 (1989).

48. J.R. Gozzard and R.L. Langford, "Remote sensing and high-resolution landscape models in predictive geological mapping", 12th Australasian Remote Sensing and Photogrammetry Conference (2004).

49. K. Rangzan, B. Sulaimani, A.R. Sarsangi and A. Abshirini, "Change detection, mineralogy, desertification mapping in east and northeast of Ahvaz City, SW Iran using combination of remote sensing methods, GIS and ESAs model", Global J. Environ. Res. 2(1), 42-52 (2008).

50. R.L. Langford, "Temporal merging of remote sensing data to enhance spectral regolith, lithological and alteration patterns for regional mineral exploration", Ore Geol. Rev. 68, 14-29 (2015). https://doi. org/10.1016/j.oregeorev.2015.01.005

51. D.I. Tommaso and N. Rubinstein, "Hydrothermal alteration mapping using ASTER data in the Infiernillo porphyry deposit, Argentina", Ore Geol. Rev. 32, 275-290 (2007). https://doi.org/10.1016/j. oregeorev.2006.05.004

52. M. Boloki and R. Poormirzaee, "Using ASTER image processing for hydrothermal alteration and key alteration minerals mapping in Siyahrud area, Iran", Int. J. Geol. 3, 38-43 (2010).

53. A.A. Green, M. Berman, P. Switzer and M.D. Craig, "A transformation for ordering multispectral data in terms of image quality with implications for noise 
removal", IEEE Trans. Geosc. Remote Sens. 26(1), 65-74 (1988). https://doi.org/10.1109/36.3001

54. R.H. Yuhas, A.F.H. Goetz and J.W. Boardman, "Discrimination among semi-arid landscape endmembers using the Spectral Angle Mapper (SAM) algorithm", Summaries of the 4th JPL Airborne Earth Science Workshop. JPL Publication, pp. 92-41, 147-149 (1992).

55. E.L. Hunter and C.H. Power, "An assessment of two classification methods for mapping Thames Estuary intertidal habitats using CASI data", Int. J. Remote Sens. 23(15), 2989-3008 (2002). https://doi. org/10.1080/01431160110075596

56. F.A. Kruse, J.W. Boardman, A.B. Lefkoff, K.B. Heidebrecht, A.T. Shapiro, P.J. Barloon and A.F.H. Goetz, "The Spectral Image Processing System (SIPS)-interactive visualization and analysis of imaging spectrometer data", Remote Sens. Environ. 44, 145-163 (1993). https://doi. org/10.1016/0034-4257(93)90013-N

57. O.A. De Carvalho and P.R. Meneses, "Spectral Correlation Mapper (SCM); an improvement on the Spectral Angle Mapper (SAM)", Summaries of the 9th JPL Airborne Earth Science Workshop. JPL Publication, Vol. 18, p. 9 (2000).

58. The Spectral Geologist. professional licence version 7.1.0.073 (July 2017).

59. E. Yetkin, V. Toprak and M.L. Suezen, "Alteration mapping by remote sensing: application to
Hasandag-Melendiz volcanic complex", Geo-Imagery Bridging Continents XXth ISPRS 30 Congress, Istanbul (2003).

60. A. Beiranvnd Pour, M. Hashim and M. Marghany, "Using spectral mapping techniques on shortwave infrared bands of ASTER remote sensing data for alteration mineral mapping in SE Iran", Int. Phys. Sci. 6, 917-929 (2011).

61. L.C. Rowan, R.G. Schmidt and J.C. Mars, "Distribution of hydrothermally altered rocks in the Reko Diq, Pakistan mineralized area based on spectral analysis of ASTER data", Remote Sens. Environ. 104, 74-87 (2006). https://doi.org/10.1016/j. rse.2006.05.014

62. R.N. Clark, G.A. Swayze, A. Gallagher, T.V.V. King and W.M. Calvin, The U.S. Geological Survey, 815 Digital Spectral Library: Version 1 (0.2 to $3.0 \mu \mathrm{m})$. US Geological Survey Open-File Report, 93-592 (1993). https://doi.org/10.3133/ofr93592

63. J.P. Richards, "Tectono-magmatic precursors for porphyry Cu-(Mo-Au) deposit formation”, Econ. Geol. 98, 1515-1533 (2003). https://doi.org/10.2113/gsecongeo.98.8.1515

64. R.H. Sillitoe, "Porphyry copper systems", Econ. Geol. 105, 3-41 (2010). https://doi.org/10.2113/gsecongeo.105.1.3 